\title{
Training and Maintenance of Use of Kefir Milk for Healing Degenerative Disease Symptoms of Tanjungsari Elderly Muslim
}

\author{
Neneng Windayani, Tuti Kurniati, Yulia \\ Sukmawardhani \\ Prodi Pendidikan Kimia, Fakultas Tarbiyah dan Keguruan \\ UIN Sunan Gunung Djati \\ Bandung, Indonesia \\ nenengwinda.ftk@uinsgd.ac.id
}

\author{
Milla Listiawati \\ Prodi Pendidikan Biologi, Fakultas Tarbiyah dan Keguruan \\ UIN Sunan Gunung Djati \\ Bandung, Indonesia
}

\author{
Nurhamzah \\ Prodi Pendidikan Agama Islam, Fakultas Tarbiyah dan Keguruan \\ UIN Sunan Gunung Djati \\ Bandung, Indonesia
}

\begin{abstract}
The dedication of Lecturers to the Society aims to improve the quality of health of the assisted elderly through the utilization of milk kefir based on the resources potential of Tanjungsari region, socialization and community empowerment, especially the elderly in the manufacture and usage of household milk kefir. This devotion uses the training method followed by mentoring for one month. The aged health parameters measured at the beginning and end of the activity include blood pressure, glucose level, cholesterol and uric acid. The results of the dedication show successfully bringing the training participants up to $150 \%$ (90 people) from the initial target. Seventy participants $(175 \%$ of the target) committed to the practice of making milk kefir, 29 people (145\% of the target) consistently produce and utilize milk kefir regularly. Participants who consistently utilized the milk kefir experienced improvement of the four health parameters measured, i.e. blood pressure, glucose, uric acid, and cholesterol with percentages of $65.5 \%$, $93.1 \%, 100 \%$ and $82.76 \%$, respectively.
\end{abstract}

Keywords—degenerative diseases; elderly; milk kefir

\section{INTRODUCTION}

Every human being wishes to have a long life with excellent health. For a Muslim, age (time) and health are two modalities to do good deeds, to be able to obtain the state of husnul khatimah at the age until the end of life. As the Messenger of Allah (SAW) once said that "Take advantage of five circumstances before the coming of five circumstances; your life before your death, your health before your illness, your spare time before your busy, your youth before your old age, your pre-dawn age "(H.R. al-Hakim and al-Baihaqi). To obtain a healthy life, it must be familiar with maintaining a healthy lifestyle, one of them by getting used to drinking milk. Rasulullah SAW said, "There is no food that can replace food and drink more than milk" (H.R. Tirmidhi). Imam Baqir said that the properties that exist in milk, especially cow's milk is to increase appetite because the stomach can be perky. Rasulullah SAW said that cow's milk has the effect of eliminating heat from the heart. Milk strengthens the back, improves the ability of the brain, strengthens the intelligence, sharpen vision, and forget [1]. Elderly health life has also become the government's attention with the issuance of Law No. 13 of 1998 on Elderly Health and Permenkes No. 25 of 2016 on National Plan of Action of the Elderly Year 2016-2019.

Based on Law no. 13 in 1998, the elderly was defined as someone who reached the age of 60 years and above. Globally, the elderly population is predicted to increase, along with the increase in UHH (life expectancy). Ministry of Health data shows that since 2004-2015 showed an improvement of UHH in Indonesia from 68.6 to 70.8 years and projection year, 20302035 reach 72.2 year [2]. The number of elderly West Java itself ranks 8th nationally (8.5\% of the population). In Sumedang District, including in Tanjungsari sub-district, the rate of growth of the elderly (between 1995-2005) averaged $5.5 \%$ per year, higher than the growth rate of children under five, which was only $1.21 \%$ [3], so that in the future the proportion of elderly people in Tanjungsari will increase. Therefore, efforts are needed to consider the socio-economic conditions including the health condition of the elderly. Up to 2016 , only $13.5 \%$ of the elderly receive health services at the Tanjungsari Health Center, where nearly $70 \%$ of them are elderly women [4]. The types of health problems that are often complained of Tanjungsari elderly include hypertension, joint pain, diabetic, hypercholesterolemia, and uric acid. These complaints include symptoms of degenerative diseases that are caused by decreased function of organs due to age. This condition certainly affects the daily activities of the elderly, 
including activities in worship, where most of the elderly in Tanjungsari as farmers, traders, and housewives with the average education level of primary school.

However, although degenerative diseases are a common and unavoidable condition, along with advances in science and technology, degenerative diseases can be prevented and even treated. One of them with the selection of proper nutrition and appropriate activities, for example by using nutrients derived from milk fermentation products, such as milk kefir. The results showed that milk kefir was able to decrease some parameters of degenerative disease symptoms between cholesterol levels, hypertension [5], and diabetic [6]. This is understandable because based on research that has been done in UIN Sunan Gunung Djati Bandung, kefir milk has complete nutrition such as carbohydrates, protein, fat, fiber, vitamins, and probiotics are good for health [7]. As the Qur'an in Surat خال صا J ب. il-Nahl (16) of verse 66 indicates that the word "(in the form of) clean milk" means the color white, taste, and sweetness is absolutely holy \& clean, nourishing and useful [8, 9]. Milk referred to in verse is cow's milk, because cow's milk is the best milk [1]

Considering that Tanjungsari Subdistrict has the superior product such as cow's milk as the basic ingredients to make milk kefir and still lack of knowledge of the society will the goodness of milk kefir for degenerative diseases, it is necessary socialization and public prosperity, especially elderly, in producing and utilizing milk kefir. Therefore, PkM activity is designed in the form of training and assistance of elderly to create and utilize milk kefir, so it is expected to reduce the symptoms of degenerative diseases in the elderly.

\section{METHOD}

- Training on Introduction and Making Kefir Milk scale household in a group conducted in collaboration with Elderly Group Prolanis (Program of Chronic Disease Management) Puskesmas and Group of LKS Aisyiyah Kecamatan Tanjungsari Sumedang District.

- The assistance of Utilization of Milk Kefir as elderly nutrition in collaboration with Prolanis Companion Officer from Tanjungsari Health Center and Facilitator of LKS Aisyiyah Tanjungsari Subdistrict.

- Measuring parameters of health conditions of elderly assisted before and after routinely utilize milk kefir for 1-2 months in collaboration with health personnel UPT Puskesmas Tanjungsari. The parameters measured include: Blood pressure, instant blood sugar levels, uric acid levels, blood cholesterol levels.

Activities are conducted in sequence Community service activities are divided into several stages, as described below:

- License handling to related parties (Kecamatan, LKS Aisyiyah, and Puskesmas of Tanjungsari Sub-district)

- Socialization and demonstration of making milk kefir to elderly groups assisted by Puskesmas and elderly groups assisted by LKS Aisyiyah.
- Implementation of training of milk kefir to elderly group assisted by Puskesmas and LKS Aisyiyah as well as the signing of elderly contract willing to produce and consume milk kefir continuously.

- Measuring health parameters of participants before and after taking kefir (one month period).

\section{RESULTS AND DISCUSSION}

The socialization and training of milk kefir were held on August 4, 2017, for the Tanjungsari sub-district Puskesmas, and on August 13, 2017, for the AKSF group of Tanjungsari sub-districts. Information about the holding of this socialization and training program on milk kefir has been conducted more or less since two weeks earlier.

Activity on August 4, 2017, begins elderly gymnastic is located in the square Tanjungsari District with the number of participants as many as 120 people. Before the elderly gymnastics took place, was pre-informed about the holding of demonstrations and training of milk kefir making. The participants' enthusiasm was quite good, as indicated by the number of participants, amounting to 70 people who were an entirely elderly group of Puskesmas sub-district of Tanjungsari District. After the gymnastic activity is complete, participants who will follow the training go into the hall room of Tanjungsari Health Center. Later, participants received a presentation on the meaning and benefits of kefir before the demonstration and training of milk kefir took place. During the event, participants took turns measuring blood conditions that included blood pressure, uric acid levels, sugar at the time, and cholesterol.

Meanwhile, the activities on 13 August 2017, with the same series of activities as before, followed by 21 participants who elderly groups are built LKS Aisyiyah. The activity took place at LKS Aisiyah Tanjungsari Subdistrict. Implementation of this activity is done by three team devotion assisted by a student, with the subject which is explained that is:

- Understanding milk kefir

- Benefits of milk kefir for the prevention of degenerative diseases

- Tools and materials for the manufacture of milk kefir

- How to make milk kefir

After completion of the explanation, the activity was then continued by filling out a questionnaire about the participants' opinions on the explanation that had been done by the devotees' team. The results of the questionnaire filling are shown in Table 1 data: 
TABLE I. RESUlTS OF QUESTIONNAIRE FILLING

\begin{tabular}{|c|c|c|}
\hline No. & Type of Questions & $\%$ Answers \\
\hline 1 & Knowledge of Kefir & 95 (do not know yet) \\
\hline 2 & Explanation of trainer & $\begin{array}{l}95 \text { (easy and preaty easy to } \\
\text { understand) }\end{array}$ \\
\hline 3 & Practice making kefir & $\begin{array}{l}65 \text { (very easy) } \\
35 \text { (pretty easy) }\end{array}$ \\
\hline 4 & $\begin{array}{l}\text { The quality of the } \\
\text { training }\end{array}$ & 67.5 (very interesting) \\
\hline 5 & The benefit of training & 77 (very useful) \\
\hline 6 & $\begin{array}{l}\text { Likely to be practiced at } \\
\text { home }\end{array}$ & 65.5 (very sure and sure) \\
\hline
\end{tabular}

As explained earlier, during the explanation activities by the resource persons, participants took turns measuring blood conditions that included blood pressure, uric acid levels, glucose sugar, and cholesterol. It was recorded that a total of 29 participants in the auxiliary group performed a complete initial and final test with the average results as presented in Table 2.

TABLE II. RESULTS MEASUREMENT OF BLOOD CONDITIONS

\begin{tabular}{lllllll}
\hline & & \multicolumn{5}{c}{ Blood Conditions } \\
\cline { 3 - 7 } No & $\begin{array}{c}\text { Mean } \\
\text { ent }\end{array}$ & $\begin{array}{c}\text { Pressure } \\
(\mathbf{m m H g})\end{array}$ & $\begin{array}{c}\text { Glucose } \\
(\boldsymbol{m g} / \mathbf{d L})\end{array}$ & $\begin{array}{c}\text { choles } \\
\text { terol } \\
(\mathbf{m g} / \mathbf{d L})\end{array}$ & $\begin{array}{c}\text { Uric acid } \\
(\boldsymbol{m g} / \mathbf{d L})\end{array}$ \\
\hline 1 & Biginning & 147 & 86 & 134 & 227.03 & 7.94 \\
2 & Final & 137 & 79 & 128 & 203.72 & 6.32 \\
\hline
\end{tabular}

While the results of blood condition measurement after treatment/consumption of milk kefir is shown by the data in Table 2. The data is obtained from participants consume kefir on a continuous basis for approximately one month, a remeasured blood condition. Measurement results show mean blood pressure 136.9/78.62 $\mathrm{mmHg}$, blood glucose (instantaneous) $128.17 \mathrm{mg} / \mathrm{dL}$, cholesterol 203,72 mg / dL, and uric acid level $6,32 \mathrm{mg} / \mathrm{dL}$. In general, the results of measurements after the regular consumption of milk kefir have improved. Comparison of blood conditions before and after treatment is one measure of the success of this devotional activity.

Other results are quite encouraging gained during mentoring activities take place, in general participants feel their health condition better, where the body feels fitter, sleep sound quality, smooth excretion, without constipation, so the body feels lighter. Some participants also found a reduction in symptoms of heartburn that has been suffered diligently apply kefir cream on the skin contact the skin is more smooth and soft. During routine consumption, kefir participants avoid the symptoms of colds and colds.

The results of the PKM outline included some of the success components of the target number of trainees present, the success of the targeted number of trainees committed to the practice, the participants committed to consuming sustained milk kefir, participants who experience health improvement after routinely consuming milk kefir.

The target of trainees present as previously planned is as many as 60 people, which is a combination of the two elderly groups of Tanjungsari sub-district. In the implementation, the number of participants who attended was as many as 90 people. Thus, it can be said that the target participants who attended reached $150 \%$. The figure shows that regarding the number of participants who attend, can be said to be successful, even exceed the target.

High attendance can be caused by the curiosity of the community, especially the elderly assisted group about what is milk kefir and how to make it. As previously described in the results of the study, on questionnaire question number one, $95 \%$ of participants have not known about milk kefir, and $77.5 \%$ said this training is very useful. This may explain the high level of training attendance.

The second indicator of success is $50 \%$ of the total number of trainees committed to the practice of making milk kefir at home. Commitment is marked by the filling of a statement. From the previously targeted number of 40 participants, participants who filled the willingness letter were 70 participants. Based on this, the percentage of success is as much as $175 \%$. PkM activity seen from the second success indicator can be said successful.

A large number of participants who are committed to carrying out the practice of making milk kefir at home can be seen from the answers of the participants on filling questionnaires, namely questionnaire number two and number three. Question number two is about resource explanation. As many as $57.5 \%$ of participants answered the explanation of the resource easily understood. Because most of the participants understood the explanation of the resource persons that contained the meaning, the benefits, and the way of making milk kefir, the questionnaire question number 3 on the ease of the practice of making milk kefir, $12.5 \%$ of participants thought that the practice of making milk kefir is very easy, 50 $\%$ and $35 \%$ stated quite easily. The practice of making milk kefir considered easy by this participant is the biggest supporting factor that causes the high percentage of participants who committed to practicing making milk kefir at home.

The third indicator of success is the participants who regularly consume and utilize milk kefir. Of the target of $50 \%$ of participants who committed to producing 20 people, recorded 29 people regularly consume and utilize milk kefir. Thus, the percentage of success of this indicator is $145 \%$. PkM activity seen from the third success indicator can be said to succeed, exceeded the target set.

The success of this indicator can be seen in answer to a questionnaire of participant number 6 that is as much as $55 \%$ of trainees answered very sure can practice making milk kefir at home. Based on the results of further observation in the field, it was also found that participants who regularly produce milk kefir, in addition to drinking for health improvement, participants also processed milk kefir produced into kefir 
derivative products that are also useful such as fruit salad, smoothies, ice cream, ice candles/sticks even made into cosmetics such as masks and toners. Kefir, in addition to consume as a health drink, can also be processed into various food products, beverages, and beauty.

The fourth success indicator is improving participants' health after consuming kefir regularly. As explained earlier, participants' health improvements are based on four parameters that are measured, i.e., blood pressure, instantaneous sugar levels, uric acid levels, and cholesterol levels.

One cause of disease in elderly is high blood pressure or commonly called for hypertension. High blood pressure or hypertension is a disorder of the blood vessels that result in supplemental oxygen and nutrients carried by the blood, obstructed to the body tissues that need it. Hypertension is a condition in which a person has an elevated blood pressure above normal that results in morbidity or mortality and mortality or mortality rates. Hypertension is a condition when a person has an increase in blood pressure above normal or chronic in a long time [10].

Hypertension or high blood is a disease of heart and blood vessel disorders characterized by an increase in blood pressure. WHO (World Health Organization) provides a normal blood pressure limit is $140 / 90 \mathrm{mmHg}$. These limits do not distinguish between age and gender [11]. Hypertension can be defined as persistent blood pressure where the systolic pressure is above $140 \mathrm{mmHg}$ and diastolic above $90 \mathrm{mmHg}$. The cause of hypertension is divided into two groups namely essential hypertension (primary) is hypertension unknown cause and possibly due to hereditary or genetic factors. Secondary hypertension is hypertension which is the result of other diseases. This factor is also closely related to lifestyle and poor diet. The most influential dietary factors are excess fat (obesity), high salt intake, smoking, and drinking. If the history of hypertension is found in both parents, then the chances of suffering from hypertension become greater. Other factors that encourage the occurrence of hypertension include stress, obesity (obesity), diet, smoking [12].

Based on the measurement of blood pressure before consumption of milk kefir, it is known that as many as 15 participants had high blood pressure. Of the 15 participants, 13 people experienced a drop in blood pressure after consuming milk kefir for one month. One person did not change, and one person had an increase in blood pressure after consumption of milk kefir. Meanwhile, when viewed as a whole, of the 29 people who regularly consume milk kefir, 19 people had decreased blood pressure, seven people were unchanged, three people had raised blood pressure.

It can be seen that as many as $65.52 \%$ of participants who regularly consume milk kefir during one month decreased blood pressure, $24.14 \%$ did not change (remain in normal condition), and $10.34 \%$ increased blood pressure. Based on these results, it is evident that with the consumption of milk kefir regularly, it can improve and maintain the health condition seen from blood pressure parameters. Participants who experienced increased blood pressure after being traced further was influenced by diet after the Idul qurban holiday, while consumption of kefir was not added.
The efficacy of kefir stabilizing blood pressure is evident in a study conducted by Gungor Kanbak of the Faculty of Pharmacy, Department of Biochemistry of Eskisehir Osmangazi University in Eskisehir, Turkey, in 2013. In the study, Kanbak used a sample of forty Sprague-Dawley rats divided into five groups. Group I is the control. In Group II Kanbak gave treatment of high concentration salt $(\mathrm{NaCl})$ saline (HS), i.e., 8\%. While in group III-V each given the intake of HS and aspirin dose $10 \mathrm{mg} / \mathrm{kg}$, HS and $10.0 \% \mathrm{~b} / \mathrm{v}$ kefir, and combined HS, aspirin, and kefir. In this research, aspirin serves as a barrier to blood tension spikes. Furthermore, Kanbak observed the parameters of blood systolic pressure, mean arterial pressure, diastolic, and pulse in mice. The observation lasted for four weeks.

The results showed that the blood pressure of rats fed a high concentration of salt solution reached $170 \mathrm{mmHg}$, significantly higher than the control. However, the blood pressure did not reach the level of hypertension. Normal rat blood pressure is 133-149 $\mathrm{mmHg}$. Mice develop hypertension when blood pressure reaches more than $200 \mathrm{mmHg}$. In the study, the group with the lowest blood pressure was the group treated with aspirin with kefir. According to Kanbak, kefir plays a role in controlling blood pressure because it is rich in calcium. As it is known, calcium can reduce blood pressure by playing an important role as a mediator in the contraction and relaxation of blood vessels.

In that study, kefir not only plays a role in controlling blood pressure but also has the potential to reduce damage to kidney function. How to inhibit the enzyme angiotensin which can cause blood vessels in the kidneys to constrict. In conclusion, kefir proved to prevent spikes in blood pressure and protect kidney function potentially.

Blood glucose is a sugar contained in the blood that is formed from carbohydrates in foods and stored as glycogen in the liver and skeletal muscles. After digestion of foods containing a lot of glucose, usually, blood glucose levels will increase, but not exceeding $170 \mathrm{mg} / \mathrm{dl}$. Many hormones participate in maintaining adequate blood glucose levels both under normal circumstances and in response to stress. Blood glucose measurement is often performed to monitor the success of this regulatory mechanism. Excessive deviations from normal, either too high or too low, indicate the occurrence of 4 homeostatic disorders and should encourage health analysts to check for etiology. Blood glucose examination is a blood glucose test performed at any time of the day regardless of the last food eaten and the person's body condition.

Based on the results of measurements of glucose levels as a whole, of the 29 participants who regularly consume milk kefir, as many as 27 participants of blood glucose levels are still in normal conditions, both before and after consumption of milk kefir. Although there are some who experience an increase, it is still below the maximum threshold for blood glucose levels at the time. One person did not change glucose levels at a time, and one person had a significant increase.

Based on these results, the consumption of milk kefir regularly, it can improve health seen from the parameters of blood glucose levels at the time. One person who has elevated blood glucose levels as significantly as possible before 
measurement has recently consumed foods with high glucose levels.

Based on the results of research conducted by Judiono, giving kefir with the concentration of $3.6 \mathrm{cc} / 200 \mathrm{~g}$ of BB in STI-induced hyperglycemia Wistar rats showed the effect of lowering blood glucose level almost near the decrease of blood glucose level by insulin 0.76 unit / $200 \mathrm{~g} \mathrm{BB}[13,14]$.

Uric acid has a function in the body, namely as an antioxidant and useful in cell regeneration. Every cell rejuvenation, we need uric acid. If the body lacks uric acid as an antioxidant, it will be a lot of oxidation or free radicals that can kill our cells. The body's metabolism naturally produces uric acid. Foods consumed also produce uric acid. Uric acid becomes a problem when the levels within the body exceed normal limits. Levels of uric acid can be determined by blood and urine test results. The normal blood uric acid reference value in males is $3.6-8.2 \mathrm{mg} / \mathrm{dL}$ whereas in women it is 2.3 $6.1 \mathrm{mg} / \mathrm{dl}[15]$.

Based on the results of measurements of uric acid levels in 29 participants who regularly consume milk kefir, overall all participants experienced a decrease in uric acid levels. Although levels after the decline were above normal levels of uric acid levels in women, the decrease in all participants, proving that consumption of milk kefir regularly can improve the quality of health seen from the parameters of uric acid levels.

Cholesterol is an essential structural component that forms the cell membrane and the external layer of plasma lipoproteins. Cholesterol can be in the form of free cholesterol or combined with long chain fatty acids as ester cholesterol. Cholesterol ester is a form of cholesterol storage found in most tissues. Cholesterol also has important significance as it becomes the precursor of a large number of steroidal compounds, such as corticosteroids, sex hormones, bile acids, and vitamin D [16].

Cholesterol is grouped by the source into two types: exogenous cholesterol present in the diet and slowly absorbed from the gastrointestinal tract into the intestinal lymph nodes. Also, there is also cholesterol that is synthesized in the body cells and called endogenous cholesterol. Normal cholesterol levels are about $160 \mathrm{mg} / \mathrm{dl}-200 \mathrm{mg} / \mathrm{dl}$. Cholesterol levels of more than $200 \mathrm{mg} / \mathrm{dl}$ already indicate a cholesterol problem that can trigger the emergence of diseases due to cholesterol or dyslipidemia. With normal cholesterol levels of $160 \mathrm{mg} / \mathrm{dl}-$ $200 \mathrm{mg} / \mathrm{dl}$ vital cholesterol functions work well. But cholesterol can harm the body if the levels are very high above $200 \mathrm{mg} / \mathrm{dl}$. When this cholesterol is present in too much amount in the blood, it can form a precipitate on the blood vessel wall causing a narrowing called atherosclerosis.

Based on the results of cholesterol measurements on 29 participants who regularly consume milk kefir, 24 people had decreased cholesterol levels while five people had an increase. Among the 24 people who experienced a decline, seven people had cholesterol levels still above $200 \mathrm{mg} / \mathrm{dl}$. To these seven people, cholesterol levels before the consumption of kefir routine are very high, need treatment with a longer period for more optimal results cholesterol levels fell below $200 \mathrm{mg} / \mathrm{dl}$.
The number of participants who experienced a decrease in cholesterol levels, proving that consumption of milk kefir regularly can improve the quality of health seen from the parameters of cholesterol levels.

Based on the results of further interviews on five participants who experienced elevated cholesterol levels after the consumption of regular milk kefir, they stated that they consume too much meat during feast days, without being offset by adequate consumption of kefir, as they do not feel any disturbance that indicates an increase in levels cholesterol. However, in this activity, the measurements taken were total blood cholesterol, i.e., LDL (Low-Density Lipid, bad cholesterol) and HDL (High-Density Lipid, good cholesterol), so that the amount of the figure on the measuring instrument is a combination of both types of cholesterol. It may be that HDL levels are higher than those of LDL.

\section{CONCLUSION}

Based on the findings and discussions of the results of PkM shows that the PkM activities succeeded in bringing the trainees up to 90 people (150\%) of the set targets (60 people), seventy participants (175\% of the target) committed to practice the production of milk kefir, 29 people (145\% of the target) consistently produce and utilize milk kefir regularly, consistent participants utilize the milk kefir to improve the four health parameters measured, i.e. blood pressure, instantaneous bloog glucose, uric acid, and cholesterol by percentage respectively $65.5 \%, 93.1 \%, 100 \%$ and $82.76 \%$ respectively.

\section{ACKNOWLEDGMENT}

This research-based PkM activities get funding DIPA UIN Sunan Gunung Djati Bandung in 2017 through Center of Community Service LP2M UIN Sunan Gunung Djati Bandung. Acknowledgments to UPT Puskesmas Tanjungsari, LKS Aisyiyah Tanjungsari, and Dapur Kefir Bandung.

\section{REFERENCES}

[1] D.I. Praja, Islamic Food Combining; Menu Sehat Nabi Muhammad. Yogyakarta: Garudhawaca, 2014.

[2] Kemenkes RI. Info DATIN. Pusat Data dan Informasi Kementrian Kesehatan RI. Kemenkes, 2016.

[3] Pemerintah Kabupaten Sumedang. Rencana Pembangunan Jangka Panjang Daerah Kabupaten Sumedang, 2016.

[4] Bappeda Kabupaten Sumedang. Rencana pembangunan jangka panjang daerah, 2016.

[5] Z. Wang, J.E. Hall, J.M. Carmo, A.A. Silva and M.E. Hall, ObesityInduced Hypertension: Interaction of Neurohumoral and Renal Mechanisms. Circulation. American Heart Journal, 2015.

[6] Y.H. Kwon, J.H. Fingert, M.H. Kuehn, and W.L.M. Alward, "Mechanisms of Disease, Primary Open-Angle Glaucoma," N Engl J Med. vol. 360, 2009, pp. 1113-1124.

[7] T. Kurniati, N. Windayani, and M. Listiawati, "Total Asam Laktat, Protein, Lemak, Karbohidrat, dan Serat Whey Kefir Susu Sapi Berdasarkan Konsentrasi Starter dan Waktu Fermentasi," In Seminar Nasional Bioteknologi UGM, 2016 (pp. 1-11).

[8] Abdullah bin Muhammad bin Abdurrahman bin Ishaq al-Sheikh, Lubābut Tafsīr min Ibnu Katsīr, Penerjemaah M. Abdul Ghoffar E.M., dkk. Bogor: Pustaka Imam asy-Syafi'I, 2003. 
[9] M.Q. Shihab, Tafsir al-Misbah; Pesan, Kesan, ddan Keserasian alQuran. Jakarta: Lentera Hati, 2002.

[10] S. Saraswati, Diet Sehat untuk Penyakit Asam Urat, Diabetes, Hipertensi, dan Stroke. Yogyakarta: A+2009.

[11] L. Marliani, dkk. 100 Question \& Answers Hipertensi. Jakarta: PT Elex MediaKomputindo, Gramedia, 2007.

[12] M. Adib, Cara Mudah Memahamu dan Menghindari.Hipertensi Jantung dan Stroke. Yogyakarta: Dianloka Pustaka, 2009.

[13] Judiono, Hadisaputro, S., Ks, I., B. Cahyono, and M. Suzery, "Effects of Clear Kefir on Biomolecular Aspects of Glycemic Status of Type 2 Diabetes Mellitus (T2DM) Patients in Bandung, West Java [Study on
Human Blood Glucose, Peptide and Insulin]," Functional Foods in Health and Disease, vol. 4, no. (8), 2014, pp. 340-348.

[14] Judiono., Djokomeljanto., and S. Hadisaputro, "Biomolecular aspects of plain kefir antidiabetic potentials," IJFNPH, vol. 5, 2012, pp. 1-2.

[15] E.C. Speicher, and J.W. Smith, Pemilihan Uji Laboratorium yang Efektif: Choosing Effective Laboratory Tests. Buku Kedokteran EGC, Jakarta, 1994.

[16] R.K. Murray, D.K. Granner, and V.W. Rodwell, Biokimia Harper (27 ed.). Jakarta: Buku Kedokteran EGC, 2009. 